ISSN: 2414-0325. Open educational e-environment of modern University, special edition (2019)

\author{
Pawel Plaskura \\ Dr Eng. \\ Faculty of Social Sciences \\ Jan Kochanowski University, Branch in Piotrków Trybunalski, Poland \\ pplaskura@ujk.edu.pl \\ ORCID: 0000-0002-8257-781X
}

\title{
PREDICTING THE EFFECTS OF THE DIDACTIC PROCESS USING FORGETTING CURVES
}

\begin{abstract}
The paper presents the method of predicting the effects of the didactic process using the forgetting curves. In the didactic process, learning and forgetting processes play an important role. The learning time, the number of repetitions and their distribution over time are important. These issues can be analyzed using a deterministic description. The flow of information and the learning process can be described thanks to the educational environment developed by the author, enabling the creation of a model of the didactic process described by differential equations. The differential equations can be represented in the form of a network of connected elements in a similar way to the electrical circuits and represented in the form of an intuitive schematic. The network can be simulated using a microsystem simulator. The use of the microsystems simulator enables simulation of the didactic process in time and prediction of effects also after its completion in the long-term. It also enables prediction of the repetitions also during the didactic process. The presented approach enables the easy creation of the macro models and enables the use of many advanced simulation algorithms. The examples of simulations of the didactic process based on the real data are included. Short and long-term simulations for individual students and groups of students are presented. An example of the prediction of the optimal repetitions is shown. Based on the results, appropriate conclusions were drawn. The issues discussed in the work may be of interest to those involved in the analysis and mathematical description of the didactic process. They can also be interesting for developers of the e-learning systems especially e-learning platforms.
\end{abstract}

Keywords: didactic process simulation; didactic process modelling; educational analogy; learning and forgetting curves; educational environment; education as microsystem

\section{Introduction}

In the didactic process, learning and forgetting processes play an important role. The learning time, the number of repetitions and their distribution over time are important. These issues can be analyzed using a deterministic description. The flow of information and the learning process can be described thanks to the educational environment (Plaskura, 2019a) developed by the author. It allows creating a model of the didactic process described by differential equations. Differential equations can be presented in the form of a network of connected elements that form a certain network (Plaskura, 2018d, 2019a). Presentation of the didactic process in the form of a network is intuitive. It gives the possibility to easily model the process and to separate the user from a complicated mathematical description.

Network analysis over time can be performed using a microsystem simulator. The results of the simulations make it possible to predict the effects of the didactic process and to conclude on how the process were conducted. In particular, you can get information about the duration of learning, the number of repetitions and the duration of the individual repetitions of the didactic material. Including the forgetting curves into the description of the didactic process, you can get information on changes in the level of knowledge (achievements) over time, also in the long period after the completion of the didactic process. The discussed approach also allows design- ing more optimal didactic processes that take into account the actual human characteristics. It is also possible to determine the duration and number of repetitions of didactic material in terms of achieving the intended effects. This is possible thanks to the advanced method and algorithms of simulation and optimization implemented in the microsystem simulator (Plaskura, 2013a). 
ISSN: 2414-0325. Open educational e-environment of modern University, special edition (2019)
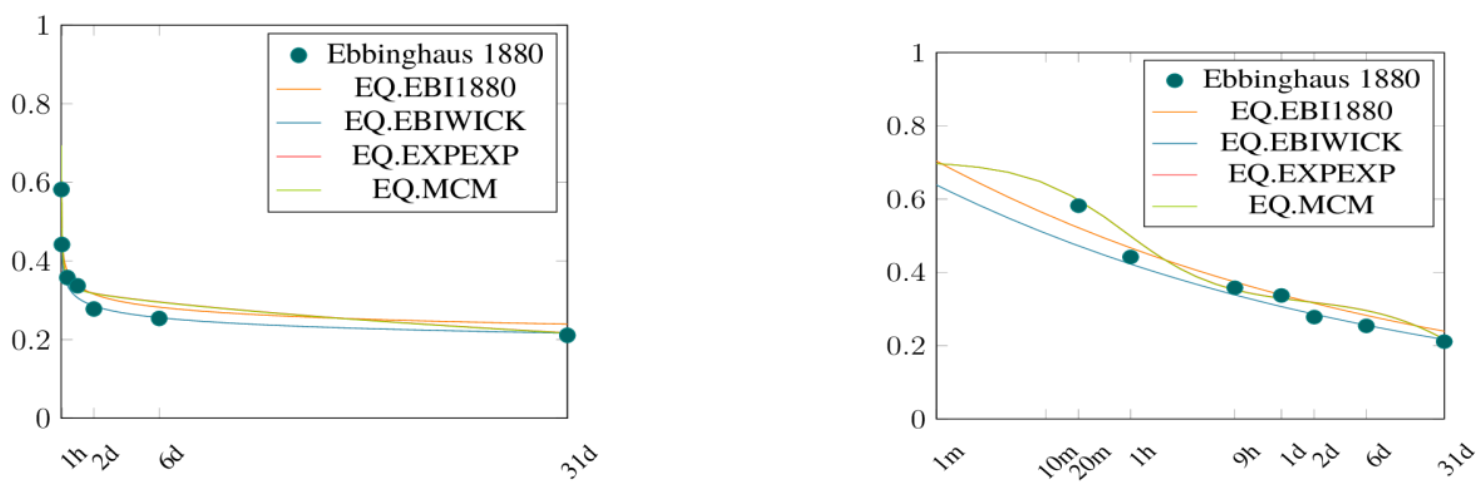

Fig. 1. Forgetting curves described by different formulas (linear and logarithmic scale)

The main reason for dealing with the subject is the apparent lack of use of modern methods of description and simulation in the didactics (Rao, Edelen-Smith, \& Wailehua, 2015). However, the mathematical models using direct mathematical formulas were previously created (Panadero, Pardo, Panadero, \& Andreas, 2002).

Related works The work uses an interdisciplinary approach. There are many scientific works in each area. The most important of them, from the point of view of the article, are cited. Detailed issues raised in the article can also be found in the articles (Plaskura, 2019c, 2018a, 2018c, 2018b, 2019a, 2019b). The initiation of the work was a series of works from various fields of science (Ebbinghaus, 1913; Panadero et al., 2002; Murre, Meeter, \& Chessa, 2007; Jaap, Murre, \& Dros, 2015) and knowledge in the field of numerical methods and microsystems simulation methods (Plaskura, 2013b, 2001).

The analysis of the learning and forgetting process is based on forgetting curves represented by the direct formulas (Ebbinghaus, 1913; Wickelgren, 1974; Jaap et al., 2015). The curve is still the subject of research and has practical application. Different functions are used to describe the forgetting curves such as power or exponential (Jaap et al., 2015). Their form and coefficients allow matching values to measured data obtained during the experiments. Superposition of functions (e.g. superposition of exponential functions functions (Woźniak \& Gorzelańczyk, 1998; Woźniak, Gorzelańczyk, \& Murakowski, 1995) and the more complicated models such as Memory Chain Model (Murre et al., 2007; Heller, Mack, \& Seitz, 1991; Rubin, Hinton, \& Wenzel, 1999) are also used. The Ebbinghaus points and different forgetting curves known from the literature are shown in Fig. 1. As you can see, none of the functional models properly describes Ebbinghaus points (Plaskura, 2019b).

The models are used to describe the efficiency of repetitive operations on production lines (Jaber \& Saadany, 2011; Anzanello \& Fogliatto, 2011; Jaber, 2011): hyperbolic and exponential models (Mazur \& Hastie, 1978; Towill, 1990; Lolli, Balugani, Gamberini, Rimini, \& Rossi, 2018), multiparameter and multidimensional models (Badiru, 1992; McIntyre, 1977; Womer, 1979).

Currently, the analysis of the didactical process is more often based on the large amounts of data (BigData) (El-Bakry, 2015; Birjali, Beni-Hssane, \& Erritali, 2018).

Forgetting curve describe a dynamic model of brain activity in the sphere of learning. The learning curves are implemented in repetitive algorithms in many programs i.e. SuperMemo ("SuperMemo", 2017), Anki ("Anki", 2017). The learning platforms also support the didactic process (Smart Learning Platforms) (Essa, 2016), but the main problem is collecting the user activity data (Whitaker, 2012; "xAPI", 2018). The mentioned above models are mainly based on the analytical equations. The models are sensitive to their parameters and are not intuitive. The discussed approach is different. It is based on a model described by differential equations. However, differential equations are difficult to arrange and solve. 
ISSN: 2414-0325. Open educational e-environment of modern University, special edition (2019)

The effective and intuitive representation of equations is the most important. The developed educational analogy, as well as network representation of the whole process, is the solution (Plaskura, 2019a). The form of a schematic (diagram) of connected elements describes the system at different levels of abstraction. The network is created by transforming the equations of the generalized network into the educational environment by using analogy (Senturia, 1998). The similar approach is also used in the model of neurons activity described in the form of an electrical circuit (Gerstner \& Kistler, 2002).

The aim of the article is showing the practical use of the developed educational environment and simulation methods in the monitoring of the didactic process.

The solutions of the network equations are, in particular, equations describing the forgetting curves known from the literature (Ebbinghaus, 1913; Wickelgren, 1974; Jaap et al., 2015). The network can be generated manually (simple didactical process) or automatically (complex didactical process) and can be easily analysed and optimized by using microsystems simulator. It enables the analysis of very complicated didactical processes. The network equations are formulated automatically thanks to the use of templates (Ho, Ruehli, \& Brennan, 1975; Ogrodzki, 1994; Plaskura, 2013a). It is possible to select the values of the elements parameters and/or change the structure of the network in terms of design constraints. Behavioural modelling enables the use of direct formulas in the element models. In the paper, developed by the author Model Definition Language (MDL) implemented in the Dero simulator was used (Plaskura, 2013a). Described above techniques have been implemented on the Quela (Plaskura, 2016) platform and used in practice. The platform was design based on the DIKW (Baškarada \& Koronios, 2013; Rowley, 2007; Kamhawi, 2017) model (Data, Information, Knowledge, Wisdom). The presented approach models the didactical process at the first, second and third level of the $D I K W$ model. The 4th level can be also modelled by user profiling what is not discussed here. Examples of simulations are discussed later in this work.

\section{The Theoretical Backgrounds}

The network of connected elements is the intuitive representation of the complicated mathe- matical formulas, especially the sets of differential equations. The network models information flows as well as information gathering in the process of learning and forgetting.

Development of the hardware description languages ("IEEE Standard VHDL Language Ref- erence Manual", 2009) leads to the microsystems simulators. The microsystems simulators can analyse the network where variables belong to different environments. Equations that occur in different environments are often the same. Thanks to that, it is possible to use analogies and to analyze of e.g. electrical-mechanical systems. Variables should be analyzed with individual ac- curacy in accordance with the specificity of the given environment, in particular, the educational environment needs i.e. long term simulations.

The educational environment variables correspond to the generalized variables and electrical variables as well. Three basic variables are information, information flow and knowledge.

\subsection{The Basic Network Elements and Their Meaning}

The use of predefined element models allows to easily create a network description using graph- ical symbols. Network equations can be formulated automatically by using the Modified Nodal Equations (Ho et al., 1975). Using the electrical schematics we can define the basic elements of the network and its equations are shown in Fig. 2. The meaning of the elements results from their equations. The Ra element models losses in the transmission of information as described above. The Ka is the source of knowledge dependent on time. The Ia is the source of informa- tion dependent on time. 
ISSN: 2414-0325. Open educational e-environment of modern University, special edition (2019)

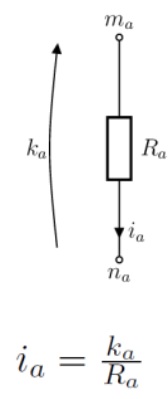

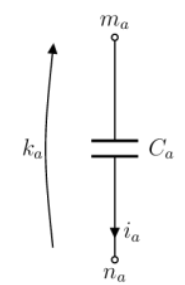

$i=C_{a} \cdot \frac{d k_{a}}{d t}$

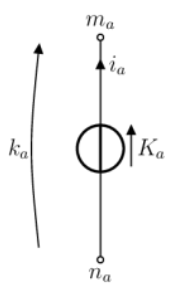

$K_{a}=f(t)$

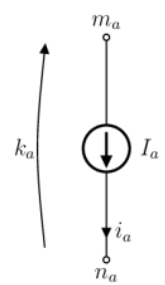

$I_{a}=f(t)$

Fig. 2. Basic elements of the network

\subsection{Didactical Process Modelling}

As mentioned above, the educational environment enables describing the didactic process in the form of the network of connected elements. The didactical process needs several models, in particular, model of the didactic unit, learning and forgetting, exam, and evaluation. The models were developed due to the DIKW (Baškarada \& Koronios, 2013; Kamhawi, 2017) describing relationships between parts of the educational process.

Profiling The information can be classified in terms of the didactic objectives. According to Bloom's Taxonomy ("Bloom's taxonomy", 2017), the main categories of learning objectives (o) can be distinguished: knowledge, comprehension, application, analysis, synthesis, evaluation. A simplified model can use for example concepts, procedures, achievements.

Thus the learning and forgetting can be simulated in relation to the categories of learning objectives $(L O)$. The values of network variables for each category of learning objectives can be used to monitor every part of the didactic process. They can also be used in the evaluation or optimization process. Every category of the learning objective is modelled separately. Profiling corresponds to modeling the experience at 4-th level (wisdom) of the DIKW model (Baškarada \& Koronios, 2013; Kamhawi, 2017).

During the learning process, the engrams or sets of engrams are created (Woźniak \& Gorzelańczyk, 1998). The process of engrams creation is still under research. Taking this into account, it can be assumed that the didactical unit $(D U)$ is related to the set of the engrams. Each engram or set of engrams are related to the didactical material (data level of the DIKW model (Baškarada \& Koronios, 2013; Rowley, 2007; Kamhawi, 2017)). Each didactical material is a part of at least one course/didactical unit. Thus the didactic process can be decomposed on the level of data.

The result of the whole didactical process is the superposition of the knowledge levels related to each didactic material. as shown in Fig. 3. The total level of knowledge changes over time due to material repetitions. Every repetition of the single DM is represented separately. The total knowledge level of the didactical course is the superposition of the knowledge level of every DU.

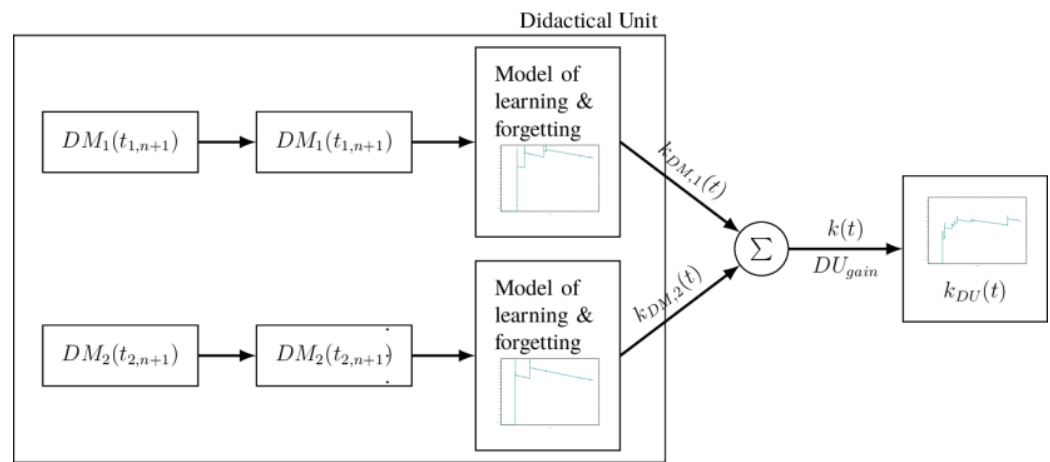

Fig. 3. Retention of the materials in the single didactical unit 
ISSN: 2414-0325. Open educational e-environment of modern University, special edition (2019)

\subsection{The Network Representation of Didactical Process}

The educational environment (Plaskura, 2019a), as well as the basic elements shown in Fig. 2, can be used to create a description of the information flows and information gathering in the process of learning and forgetting. Different functions are used to describe the forgetting curve (Jaap et al., 2015), in particular power, exponential, and superposition of functions. As shown in the (Woźniak \& Gorzelańczyk, 1998). The superposition of the exponential function probably the better describe the forgetting curve than the power function. The network representation of the learning and forgetting process is studied in (Plaskura, 2019b, 2018d). In the work, the piecewise linear model (Fig. 4) was used.
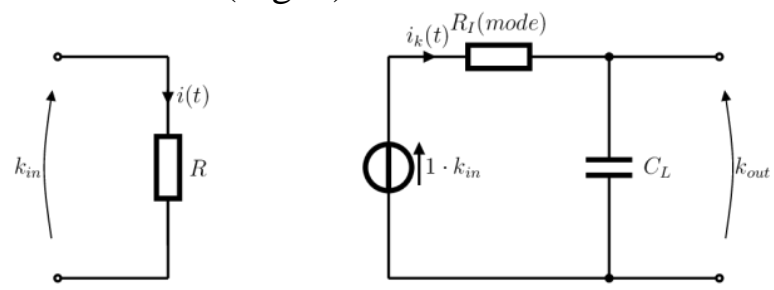

Fig. 4: Piecewise linear model of learning and forgetting

The model is relatively simple and in this form do not fit all points on the forgetting curve (Ebbinghaus, 1913). The more complex model is required. The model takes into account every category of learning objectives. Parameters of elements can be dependent, for example, on time and/or mode. The model enables flexible modelling by changing the time constant $\tau=R_{I} C_{L}$. It is realized by changing the $R_{I}$ parameter. The mode denotes learning or forgetting. The repetition of the material is also taken into. The initial values of $\tau$ are as follow (Plaskura, 2018c): about 20..31minutes for learning, about 9..12hours for short time forgetting, about 31..43.4days for a long time forgetting. The values changes in time due to i.e. the material repetition. The model describes the learning process for the isolated part of the material which creates single engram or set of engrams.

Network representation of material repetitions The example (Plaskura, 2019a) of the net- work representation of the 3 repetitions of the same didactical material is shown in Fig. 5 .

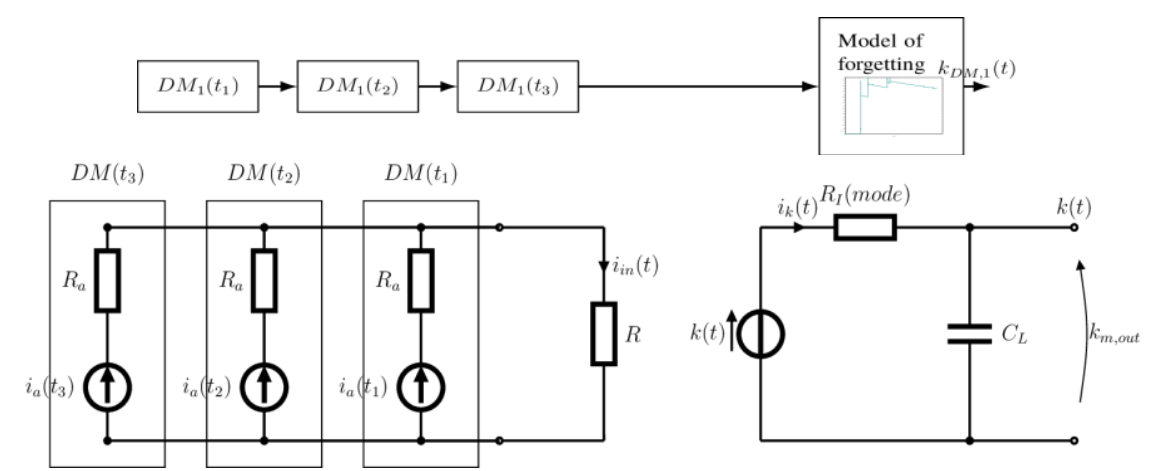

Fig. 5. Network representation of repetition of the didactical material

Didactical unit (DM) is repeated 3 times at different time points $t_{1} \ldots 3$. The learning and forgetting model consists of elements: $R, k, R_{l}, C_{L}$. The model parameters depend on the mode (learning or forgetting), the number of repetition and the time constants described in (Plaskura, 2019a, 2018d). All categories of the learning objectives are modelled - Bloom's Taxonomy ("Bloom's taxonomy", 2017).

Evaluation of the results Tests or examinations results for individual learning can be com- pared with the simulation results. The comparison can also be modelled. If the results do not match the results of the simulation, a re-check of knowledge should be considered. 
ISSN: 2414-0325. Open educational e-environment of modern University, special edition (2019)

Evaluation of the didactical process carried out by determining the appropriate user profile for each The achievements in the category of learning objectives can also be taken into account. It is possible to determine whether a given user profile is preserved or not.

\section{Results and Discussion}

The examples of the application of the system in practice are presented below. You can use it to the prediction of effects, simulation of the didactic process in the long term, reasoning in how to conduct the process, inference about the exam strategy, design and optimization.

The system described above was used in practice. Several assumptions have been made. The output gain is a superposition of the gains for every part of the course. The courses were simulated individually for each student based on their activities. The results of the simulation are compared with the real results obtained during the exams. Questions cover all topics what means the uncertainty of the assessment will not occur. The minimal score of the test was set to $0.51(51 \%)$. Final grades are within limits $(0.51 . .0 .60,0.61 . .0 .70,0.71 . .0 .80,0.81 . .0 .90$, $0.91 . .1 .00)$.

Individual simulation Example of the student activities during the didactical process for In- formation Security (IS) course is shown in Fig. 6. The BI - Knowledge represents simulated results of the designed course. The simulated level of student knowledge represents the variable of Knowledge. The real level of student knowledge obtained during the exam represents Evaluation. The initial level of knowledge was set to 0. The default parameters of the learning and forgetting process were set.

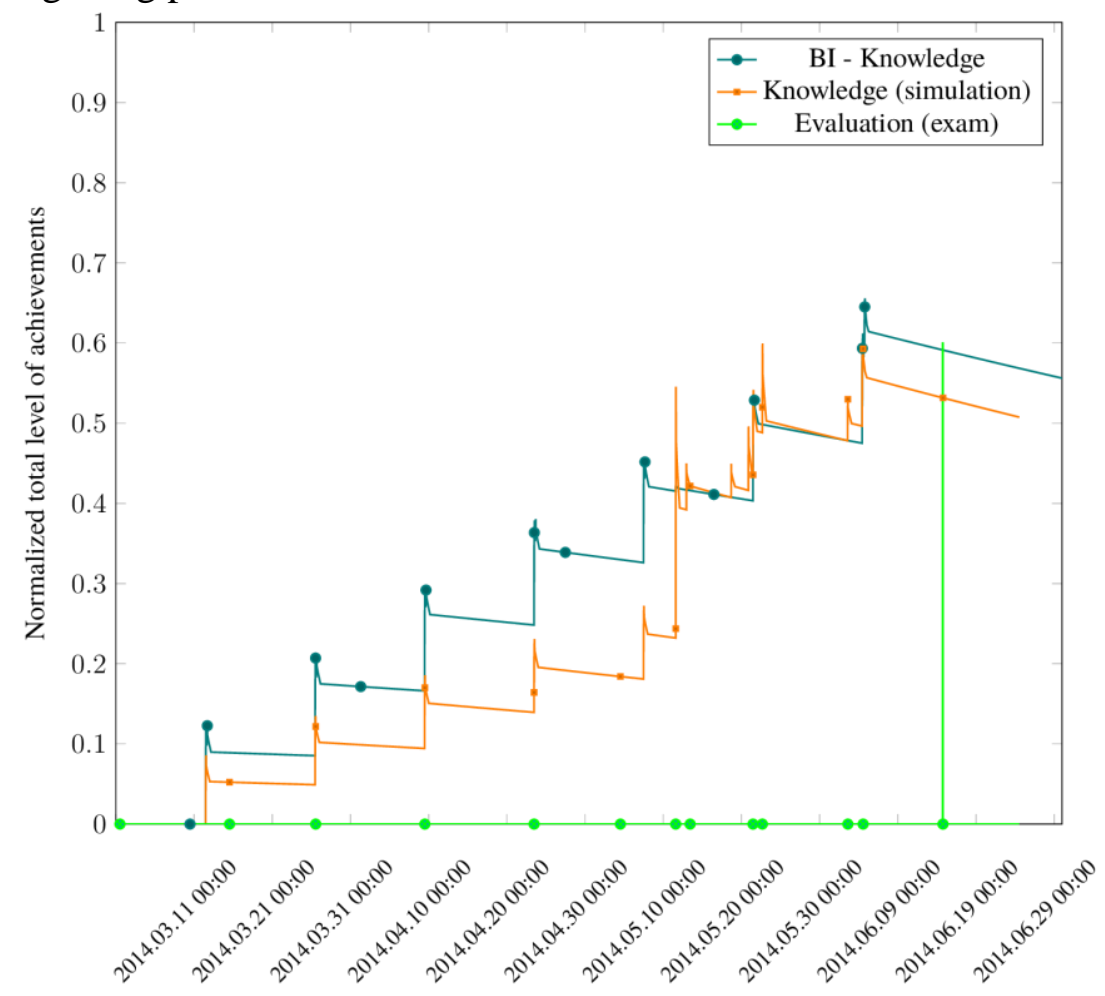

Fig. 6. Didactical process simulation for IS course based on the student's activity

The simulation does not include activities that took place outside the registered didactical process. Because of this, there are differences between the simulated and real process. The simulation results are all the more accurate the more ac- tivity data is available. The expected level of knowledge differs from the real level at around $10 \%$. As can be seen, there are no visible activities before the exam. It means that the student did not use the system - worked off-line on his own materials. Further information and simu- lation results, including long-term simulations after completing the course, can be found in the literature (Plaskura, 2018a, 2018c, 2018d). 
ISSN: 2414-0325. Open educational e-environment of modern University, special edition (2019)

Long-term simulation The use of simulation enables didactic process simulation for a long period of time. In the example, the long-term simulation results for two course IT (Information technology) an IS (Information security) are shown in Fig. 7.

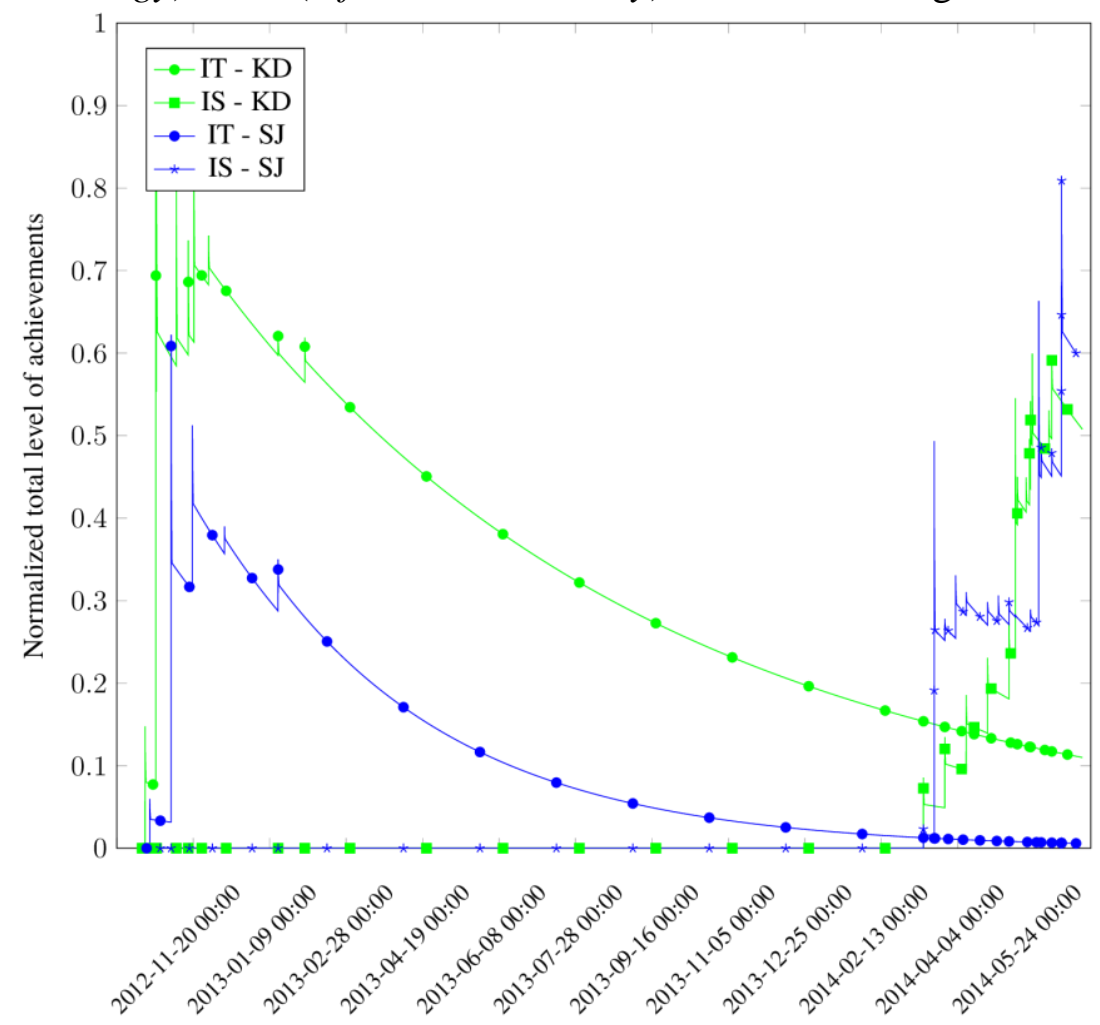

Fig. 7. Long-term simulation results for $I T$ and $I S$ courses.

The results for the two students (TD and SJ) are printed. At the left side learning activities for the IT course are shown. At right side activities for the IS are printed. The TD student is very active in both courses. The slope of the forgetting curve is smaller. At the beginning of the IS course, the level of achievement associated with the IT course is still at the level of $15 \%$. It was assumed that the student has not repeated the material. It means that the student works hard and many times repeated the materials during the IT course. The SJ student has not worked hard. The large slope shows that. At the beginning of the IS course, his knowledge was almost forgotten. For the IS course, the situation is a bit different. SJ student is more active.

As can be seen, the slope of the forgetting curve denotes the level of memorization. If the slope is small it denotes that the knowledge is well memorized. For full memorization, the curve approaches a horizontal straight line.

Optimal repetitions of the material Material repetitions are very important in memorizing. The didactic process consists of many didactic materials forming engrams. The simulation results are shown in Fig. 8. The minimal level of memorization is set to 0.75 . The memorization level is set to every part of the didactic process. The minimal time gap between repetitions is set to 7 days what often occurs in practice. The dotted line shows the didactic process without repetitions. Maintaining level 0.75 requires many repetitions of the materials. The 0.75 level was maintained at the time of the exam. It was not shown which materials were repeated. The length of time of individual repetitions is also not shown. The resultant curve is a superposition of many curves related to particular didactic materials. 
ISSN: 2414-0325. Open educational e-environment of modern University, special edition (2019)

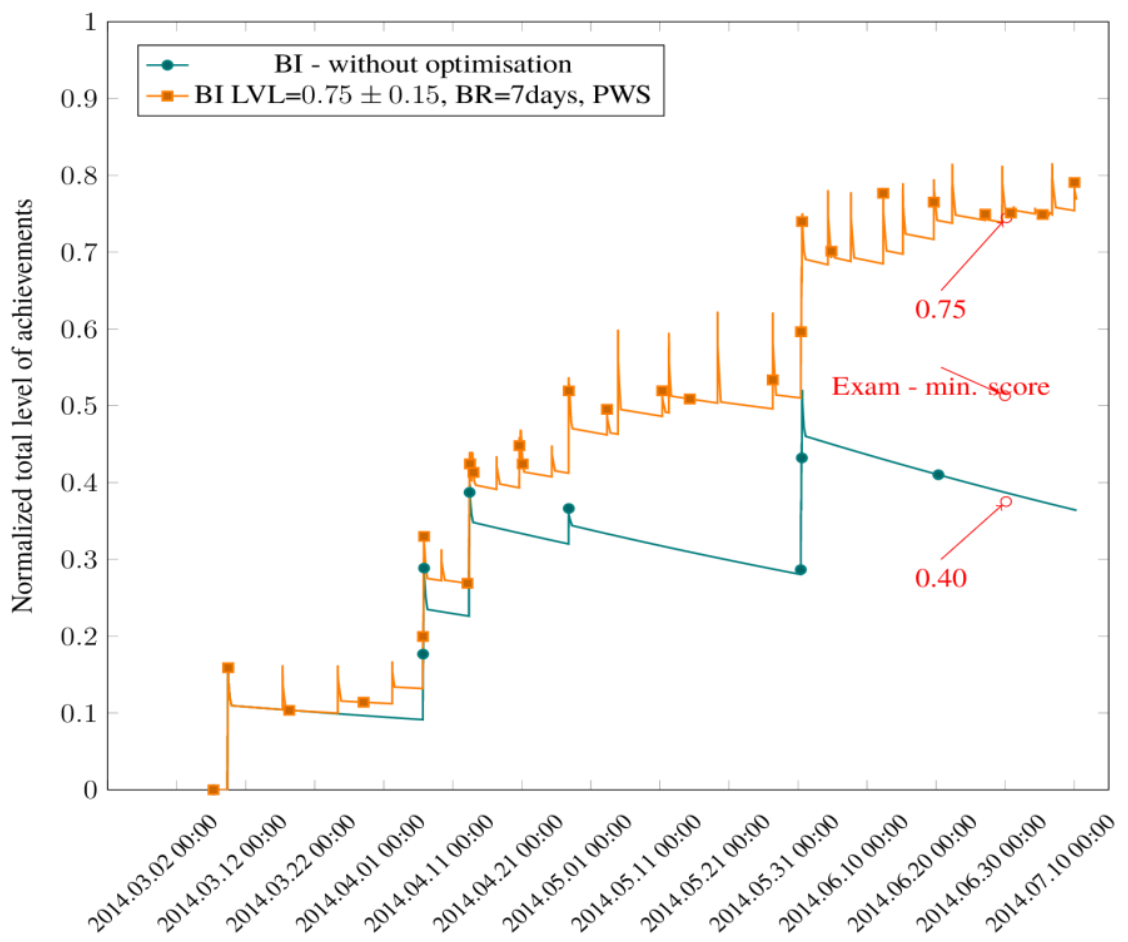

Fig. 8. Simulation results IS course.

Simulations for groups of students The example of simulations for groups of students (IT course - 1-sem. 30h - the English Philology) is shown in Fig. 9.

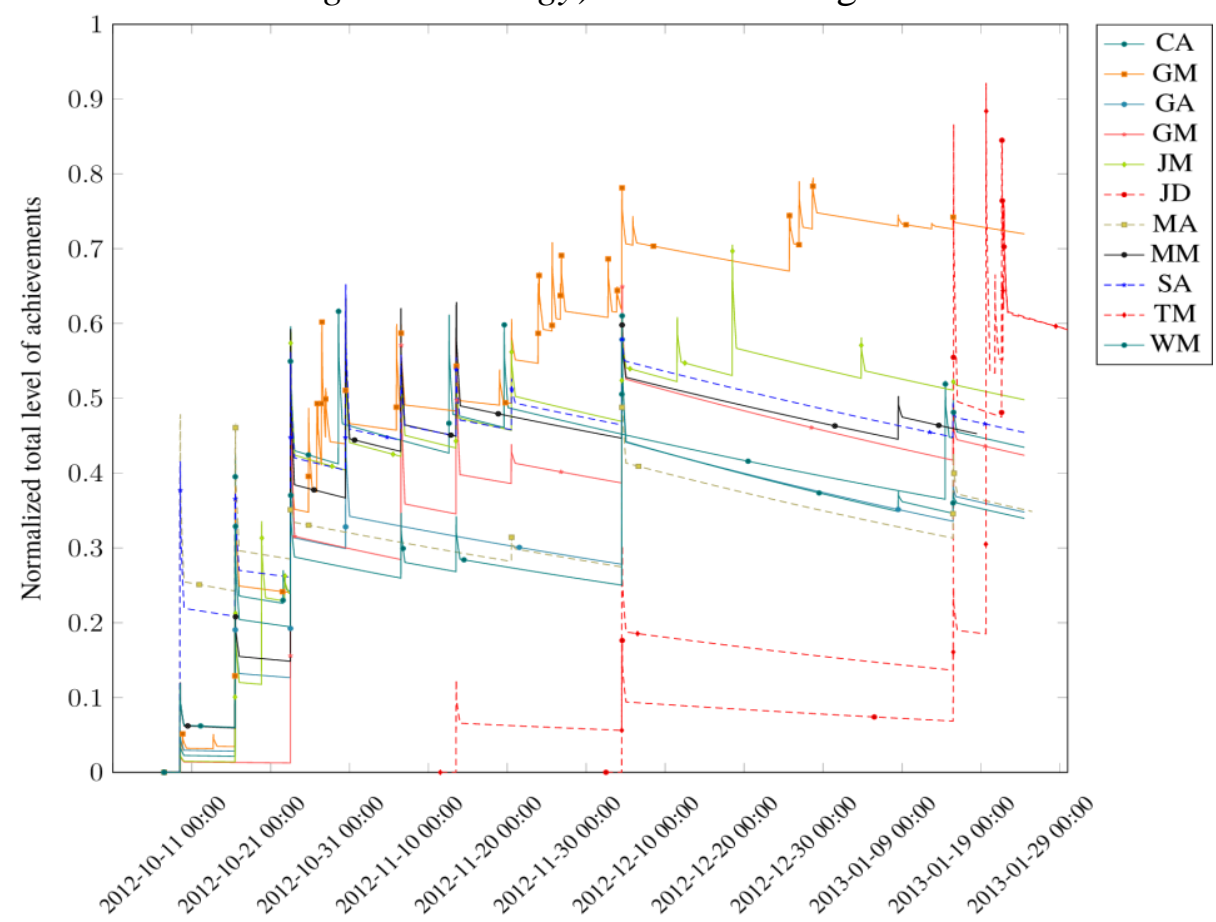

Fig. 9: Simulations for group of students

In the example, the initial condition were set to 0 according to the results of the initial test. The chart shows the students' activity over time. You can also see involvement in the didactic process. Students who are more involved use materials more often and learn more often. The slope of the forgetful curve is in this case small. Some students (TM,JD) rarely use materials, but their activity increases at the end of the teaching process before completion. This can be a sign of low motivation or copying didactic materials and using them offline. Copying didactic 
materials is very common and leads to malfunctioning of the simulation system due to lack of information about activities. However, such cases should be analyzed individually. There is one leader (GM) in the group that is very active. The remaining part of the group shows average activity. The group includes people with low activity (JD,GM). Looking at the slope of the curves of forgetting, you can see that only one person (GM) has the appropriate level of memorized knowledge. Other students require more training.

\section{Conclusions and Prospects for Further Research}

The article presents the applications of the developed description method in practice. Simula- tion results for a single student, group are shown. Simulation results for long periods of time including, for example, two courses are shown. The application of systems for selecting rep- etitions of didactic material is presented, which is very important from the point of view of efficiency.

The presented system uses a microsystem simulator and a behavioural model description language. It allows you to easily create your own models and modify existing models.

The models used in the simulation do not take into account many phenomena, eg higher learning effectiveness in the morning. However, they can be easily expanded. The optimization mechanisms included in the simulator enable individual selection of learning parameters for each student.

As shown the didactic process can be represented in the intuitive form of schematics (here electrical like) - other notations can also be used due to the analogy. The network should be generated automatically based on the student's activities. The simulation results are very sensitive to the parameters of models, in particular, the time constants in the model of learning and forgetting.

The presented system can be used, for example, on e-learning platforms or as a separate system. The presented approach gives access to many advanced simulation and optimization methods and algorithms implemented in the simulators. It enables designing more ergonomic didactic processes. The approach allows reducing the time and costs of designing the didactic process.

The practical implementation of the system on the Quela platform is still used in the research. Further work will focus on development of the models, reduction of the simulation time and using more advanced techniques (i.e. ODOS (Ogrodzki, 1986)) to analyze the parameters of the didactic process.

\section{REFERENCES}

Anki. (2017).

https://apps.ankiweb.net

Anzanello, M. J. \& Fogliatto, F. S. (2011). Learning curve models and applications: Literature review and research directions. International Journal of Industrial Ergonomics, 41(5), 573-583. doi:10.1016/j.ergon.2011.05.001

Badiru, A. (1992). Computational survey of univariate and bivariate learning curve models.

IEEE Trans. Eng. Manage. 39, 176-188.

El-Bakry, H. (2015). Handling big data in e-learning. International Journal of Advanced Re- search in Computer Science \& Technology, 3, 47-51.

Baškarada, S. \& Koronios, A. (2013). Data, Information, Knowledge, Wisdom (DIKW): A semi- otic Theoretical and Empirical Exploration of the Hierarchy and its Quality Dimension. Australasian Journal of Information Systems, 18(1). http:// journal.acs. org.au/index.php/ajis/article/view/748

Birjali, M., Beni-Hssane, A., \& Erritali, M. (2018). A novel adaptive e-learning model 
ISSN: 2414-0325. Open educational e-environment of modern University, special edition (2019)

based on big data by using competence-based knowledge and social learner activities. Applied Soft Computing, 69, 14-32. doi:10.1016/j.asoc.2018.04.030

Bloom's taxonomy. (2017).

http://www.aritzhaupt.com/eBook_ADDIE/design. html\%5C\#Introduction_to_Design

Ebbinghaus, H. (1913). Memory: A contribution to experimental psychology. Original work published 1885.

https://web.archive.org/web/20051218083239/

http ://psy.ed.asu.edu:80/\%20classics/Ebbinghaus/index.htm

Essa, A. (2016). A possible future for next generation adaptive learning systems. Smart Learning Environments, 3(1), 16. doi:10.1186/s40561-016-0038-y

Gerstner, W. \& Kistler, W. (2002). Spiking Neuron Models: Single Neurons, Populations, Plas- ticity. Cambridge University Press.

Heller, O., Mack, W., \& Seitz, J. (1991). Replikation der Ebbinghaus'schen Vergessenskurve mit der Ersparnis-methode: Das Behalten und Vergessen als Function der Zeit. Zeitschrift für Psychologie, (199), 3-18. analysis.

Ho, C., Ruehli, A., \& Brennan, P. (1975). The modified nodal approach to network

IEEE Trans. Circuits Syst. CAS-22(6), 504-509.

IEEE Standard VHDL Language Reference Manual. (2009). IEEE Std 1076-2008 (Revision of IEEE Std 1076-2002), c1-626. doi:10.1109/IEEESTD.2009.4772740

Jaap, M., Murre, J., \& Dros, J. (2015). Replication and Analysis of Ebbinghaus' Forgetting Curve. Plus One, 2, 396-408. doi:10.1371/journal.pone.0120644 2016.

Jaber, M. (Ed.). (2011). Learning curves: Theory, models, and applications. eBook - PDF

Boca Raton: CRC Press.

Jaber, M. \& Saadany, A. (2011). An economic production and manufacturing model with learn- ing effects. International Journal of Production Economics, 131 (1), 115-127.

Lolli, F., Balugani, E., Gamberini, R., Rimini, B., \& Rossi, V. (2018). A human-machine learn- ing curve for stochastic assembly line balancing problems. IFAC-PapersOnLine, 51(11), 1186-1191. 16th IFAC Symposium on Information Control Problems in Manufacturing INCOM 2018. doi:10.1016/j.ifacol.2018.08.429

Mazur, J. \& Hastie, R. (1978). Learning as accumulation: A re-examination of the learning curve. Psychol. Bull. 85, 1256-1274. $149-160$.

McIntyre, E. (1977). Cost-volume-profit analysis adjusted for learning. Manage. Sci. 24,

Kamhawi, E. (2017). The three tiers architecture of knowledge flow and management activities. October 12, 2010.

http ://www. sciencedirect . com / science / article / pii / S1471772710000321

Murre, J., Meeter, M., \& Chessa, A. (2007) In M. Wenger \& C. Schuster (Eds.), Statistical and Process Models for Neuroscience and Aging (Chap. Modeling amnesia: Connectionist and mathematical approaches, pp. 119-162). Mahwah, NJ: Lawrence Erlbaum.

Ogrodzki, J. (1986). One-dimensional orthogonal search-a method for a segment approximation to acceptability regions. International Journal of Circuit Theory and Applications. doi:10. 1002/cta.4490140302

Ogrodzki, J. (1994). Circuit simulation methods and algorithms. Boca Raton, USA: CRC Press. Panadero, M. F., Pardo, A., Panadero, J. F., \& Andreas, M. (2002). A mathematical model for reusing student learning skills across didactical units. 32nd ASEE/IEEE Frontiers in Education Conference.

Plaskura, P. (2001). Kierowana zdarzeniami symulacja systemów analogowych o opisie 
behaw- ioralnym (Event-driven simulation of analog systems with behavioral description) (praca doktorska (PhD dissertation), Politechnika Warszawska (Warsaw University of Technology), Warszawa).

Plaskura, P. (2013a). Symulator mikrosystemów Dero v4. Metody i algorytmy obliczeniowe, modelowanie behawioralne, przykłady. (Microsystems simulator Dero v4. Computational methods and algorithms, behavioral modelling, examples.) AIVA. http://epub.aiva.pl/?isbn=978-83-937245-1-2

Plaskura, P. (2013b). Zaawansowane metody symulacji układów elektronicznych. Metody i algo- rytmy obliczeniowe. (Advanced methods of electronic circuit simulation. Computational methods and algorithms.) AIVA.

http ://epub.aiva.pl/?isbn $=978-83-937245-0-5$

Plaskura, P. (2016). Quela - a platform for managing the didactical process. Матеріали Міжнародної науково-практичної конференції: Методика навчання природничих дисциплін у середній та вищій школі (XXIII Каришинські читання), Poltava,Ukraine

Poltava V.G. Korolenko National Pedagogical University, 337-340. Materials of the International Scientific and Practical Conference: Methodology of teaching natural sciences in secondary and high school (XXIII Karischinskiy reading).

Plaskura, P. (2018a). Assessing the quality of the didactic process on the base of its monitor- ing with the use of ICT. Педагогічні науки: теорія, історія, інноваційні технологiï (Pedagogical Sciences: Theory, History, Innovative Technologies), 76(2), 185-196. doi:10.24139/2312-5993/2018.02/185-196

Plaskura, P. (2018b). Dero 4 simulator as a didactical tool. ABID, 23(1), 44-51. Retrieved from http://abid.cobrabid.pl

Plaskura, P. (2018c). The use of ICT in improving the effectiveness of the didactical process. Педагогічні науки: теорія, історія, інноваційні технології, (17), 152-159. http://dspace.pnpu.edu.ua/handle/123456789/9739

Plaskura, P. (2018d). Wykorzystanie technologii informacyjnych do modelowania i monitorowa- nia jakości procesu dydaktycznego (The use of information technology for modelling and monitoring the quality of the didactical process). Piotrków Trybunalski: Wydawnictwo Uniwersytetu Jana Kochanowskiego.

Plaskura, P. (2019a). Educational analogy dedicated for didactical process simulation. Proceed- ings of the 15th International Conference on ICT in Education, Research and Industrial Applications. Integration, Harmonization and Knowledge Transfer. 1, 286-301. http://ceur-ws.org/Vol-2387/20190286.pdf

Plaskura, P. (2019b). Modelling of Forgetting Curves in Educational E-environment. Informa- tion Technologies and Learning Tools, 71(3), 1-11.

Plaskura, P. (2019c). Monitorowanie jakości procesu dydaktycznego z wykorzystaniem ICT (Monitoring the quality of the didactical process with the use of ICT). In M. Leshchenko, O. Zamecka-Zalas, \& I. Kiełtyk-Zaborowska (Eds.), Globalne i regionalne konteksty w edukacji wczesnoszkolnej. Wydawnictwo Uniwersytetu Jana Kochanowskiego w Kielcach Filia w Piotrkowie Trybunalskim.

Rao, K., Edelen-Smith, P., \& Wailehua, C.-U. (2015). Universal design for online courses: Ap- plying principles to pedagogy. Open Learning: The Journal of Open, Distance and e- Learning, 30(1), 35-52. doi:10.1080/02680513.2014.991300

Rowley, J. (2007). The wisdom hierarchy: Representations of the DIKW hierarchy. Journal of Information Science, 33(2), 163-180. doi:10.1177/0165551506070706

Rubin, D., Hinton, S., \& Wenzel, A. (1999). The precise time course of retention. Journal of Experimental Psychology: Learning, Memory, and Cognition, 1161-1176.

Senturia, S. (1998). Cad challenges for microsensors, microactuators and microsystems. 
ISSN: 2414-0325. Open educational e-environment of modern University, special edition (2019)

Proc. of the IEEE, 86, 1611-1626.

SuperMemo. (2017). Retrieved from https://www.supermemo.com

Towill, D. (1990). Forecasting learning curves. International Journal of Forecasting, 6 (1), 25-38.

Whitaker, A. (2012). An Introduction to the Tin Can API. The Training Business.

Wickelgren, W. (1974). Single-trace fragility theory of memory dynamics. Memory and Cog- nition, 2, 775-780.

Womer, N. (1979). Learning curves, production rate and program costs. Management Science, 25 (4), 312-319.

Woźniak, P., Gorzelańczyk, E., \& Murakowski, J. (1995). Two components of long-term mem- ory. Acta Neurobiologiae Experimentalis, 55, 301-305.

Woźniak, P. \& Gorzelańczyk, E. (1998). Hypothetical molecular correlates of the twocomponent model of long-term memory. The 7-th International Symposium of the Polish Network of Molecular and Cellular Biology UNESCO/PAS.

xAPI. (2018).

http://www.xapi.com

\title{
ПРОГНОЗУВАННЯ НАСЛІДКІВ ДИДАКТИЧНОГО ПРОЦЕСУ 3 ВИКОРИСТАННЯМ КРИВИХ ЗАБУВАННЯ
}

\author{
Павел Пласкура \\ доктор технічних наук \\ Факультет соціальних наук \\ Університет Яна Кохановського, філія в Пйотркув Трибунальський, Польща \\ pplaskura@ujk.edu.pl \\ ORCID: 0000-0002-8257-781X
}

\begin{abstract}
Анотація. У статті представлений метод прогнозування наслідків дидактичного процесу 3 використанням кривих забування. У дидактичному процесі важливу роль відіграють процеси навчання і забування. Важливими є час навчання, кількість повторень і їх розподіл в часі. Ці проблеми можуть бути проаналізовані 3 використанням детермінованого опису. Потік інформації та навчальний процес можуть бути описані завдяки освітньому середовищу, розробленому автором, що дозволяє створити модель дидактичного процесу, описаного диференціальними рівняннями. Диференціальні рівняння можуть бути представлені у вигляді мережі пов'язаних елементів аналогічно до електричних ланцюгів і представлені у вигляді інтуїтивної схеми. Мережа може бути змодельована 3 використанням симулятора мікросистем. Використання симулятора микросистем дозволяє моделювати дидактичний процес у часі і прогнозувати його наслідки також після завершення процесу в довгостроковій перспективі. Він також дозволяє прогнозувати повторення також під час дидактичного процесу. Представлений підхід дозволяє легко створювати макромоделі i дозволяє використовувати багато сучасних алгоритмів моделювання. Наведені приклади моделювання дидактичного процесу на основі реальних даних. Представлені короткострокові i довгострокові симуляції для окремих студентів і груп студентів. Наведено приклад прогнозування оптимальних повторень. На підставі отриманих результатів були зроблені відповідні висновки. Питання, що обговорюються в роботі, можуть представляти інтерес для тих, хто займається аналізом і математичним описом дидактичного процесу. Вони також можуть бути цікаві для розробників систем електронного навчання, особливо платформ електронного навчання.
\end{abstract}

Ключові слова: симуляція дидактичного процесу; моделювання дидактичного процесу; освітня аналогія; криві навчання та забування; освітнє середовище; освіта як мікросистема 